foreign and Japanese scientists to assess its physics department in January 1993.

Similar reviews followed of the STA's Institute of Physical and Chemical Research (RIKEN), and the Ministry of Education's Institute of Space and Astronautical Science. And MITI has given its 15 institutes some autonomy in deciding how to spend their funds. In return it has asked them for more accountability, in particular the introduction of external reviews to ensure they remain at the forefront of basic research.

The situation in neighbouring Taiwan and South Korea is very different. Two years ago South Korea launched its "G7" project, under which the government and industry plan to invest 3,400 billion won (US\$4.2 billion) by 2001 to catch up with the technological achievements of the world's seven leading industrial nations.

Some South Korean researchers carrying out very basic research in fields such as structural biology have managed to win funds from this project. But its main focus is on specific technologies, such as highdefinition television, megabit semiconductor chips, new materials and biotechnology.

Similarly, the Taiwanese government, which has traditionally supported university and academic research much better than its neighbour Japan, has introduced a policy of supporting research aimed at specific technological goals.

The National Science Council (NSC) has cut funds for investigator-initiated grants by 20 per cent, and is diverting the money to university-industry consortia for "missionoriented" research in ten areas, ranging from consumer electronics to aeronautics. The NSC says it is doing this because university researchers have placed too much emphasis on publishing papers and pursuing theoretical studies.

Japan, which in the past has been in the forefront of countries pushing technologyorientated research, is under pressure to return to this approach. Government officials such as those who helped launch the HFSP are becoming concerned that, because of the tendency of their colleagues to use developments in the West to argue for new projects, there may be a swing back to more applied research just as efforts to support basic research are getting off the ground.

There are similar fears in industry. Many Japanese companies set up well-funded basic research institutes during the boom of the late $1980 \mathrm{~s}$. Their official line is that they have no intention of cutting back on basic research, and that any cuts in spending have been part of across-the-board cuts for research and development; if anything, they claim, basic research has suffered the least.

But researchers in these institutes fear that as the recession continues to bite management may begin to look on these new institutes as a luxury they cannot afford or at least to direct their research more towards applications.

David Swinbanks

\section{Europe flexes its muscles}

Paris. The joint research efforts of the 12 member states of the European Union(EU) jumped from relative obscurity into the political spotlight at the end of 1993. This year will see how much talk is translated into action.

At their summit meeting in December, the EU heads of states endorsed a white paper (policy document) from Jacques Delors, the president of the European Commission, giving considerable importance to support of research.

Two events in 1993 changed the face of EU research politics. The Maastricht Treaty came into force in November, giving new powers to the European Parliament. The main change is that the parliament, like the member states, can now veto the Framework budget; and it has been quick to insist that this power of veto carries the right to shape EU policy from the outset.

Reinforcing this message, the parliament organized a big European Science Summit in Brussels in October. The takehome message was that it wants the fifth Framework, which will start in 1998 , to support more research into the social and economic impact of science. The parliament also wants more spent on research in renewable energy, life sciences, environment and new industrial technologies.

The other twist was the commission's decision to delegate management of an entire ECU24 million (US\$27 million)

\section{IMAGE \\ UNAVAILABLE \\ FOR COPYRIGHT REASONS}

\section{Unrivalled: with the SSC's demise, eyes are on Europe's Large Hadron Collider.}

plant molecular project to a group of scientists. If the experiment succeeds, the commission will probably set up similar structures in other research areas. This signals an important shift in policy. Previously, suggestions that bodies such as the European Science Foundation could administer EU research programmes have been quickly dismissed by the commission.

Any development to decentralize research administration from Brussels would tie in neatly with Delors' plans to encourage EU member states to do more to coordinate their national science policies.

Declan Butler

\title{
Germany: still feeling the pinch
}

Munich. Germany has long been one of the world's biggest spenders on research and development. Indeed, for several years it has come top of the league for spending on civilian research as a proportion of gross national product. But the picture is no longer so rosy. With reunification continuing to drain coffers already under pressure from the world recession, government research budgets have been frozen.

Last year, the Federal Ministry of Research and Technology (BMFT), which handles over half of the total government research budget, had to make do with the same amount of cash - around DM9.4 billion (US\$5.5 billion) - as in 1992. This figure will not increase significantly in 1994; and with inflation expected to be over 4 per cent, that effectively means a cut in spending.

The government wants industry to benefit much more from public investment in research. So far, and despite urging from certain sectors of industry and the country's Social Democrats, it has resisted pressure to achieve this aim merely by shifting funds from basic to applied research.

In contrast, the government's main con- cern at present is to increase the efficiency with which research results are transferred out of the laboratory into industry. Funding of basic research, at nearly 40 per cent of the BMFT budget, is generous. But Germany is aware that it has been slower to turn the products of research into wealth-creating products than its main competitors, the United States and Japan.

In addition, Germany faces public hostility towards key technologies, particularly biotechnology and genetic engineering. Expressed through stringent legislation controlling genetic experiments, this hostility has been a major disincentive for industry to invest in this area.

Chancellor Helmut Kohl's coalition government is keen to address both issues, and to create a more friendly environment for both industry and applied research. The gene laws have already been revised to make them less restrictive. And Paul Krüger, the research minister, has various plans to bring researchers and industry into closer contact.

Last summer, for example, Krüger set up a technology council made up of twelve representatives from industry and the 